\title{
Anaesthesia of Rainbow Trout (Oncorhynchus mykiss) with 2-phenoxyethanol: Acute Toxicity and Biochemical Blood Profile
}

\author{
J. VELÍŠEK ${ }^{1}$, Z. SVOBODOVÁ2,3 \\ ${ }^{1}$ University of South Bohemia, Faculty of Agriculture, České Budějovice \\ ${ }^{2}$ University of South Bohemia, Research Institute of Fish Culture and Hydrobiology, Vodňany \\ ${ }^{3}$ University of Veterinary and Pharmaceutical Sciences, Brno, Czech Republic \\ Received December 2, 2003 \\ Accepted June 17, 2004
}

Abstract

Velíšek J., Z. Svobodová: Anaesthesia of Rainbow Trout (Oncorhynchus mykiss) with 2phenoxyethanol: Acute Toxicity and Biochemical Blood Profile. Acta Vet. Brno 2004, 73: 379-384.

The aim of the present study was to assess acute toxicity of 2-phenoxyethanol in rainbow trout, and to assess changes in their tissues using biochemical blood profile indices. Acute toxicity values of 2-phenoxyethanol for six-month old rainbow trout ascertained by the OECD 203 ,Test of Acute Toxicity for Fish" were 0.46 (10minLC50), 0.34 (10minLC0.1), $0.92 \mathrm{ml} \cdot \mathrm{1}^{-1}$ (10minLC99.9), 0.25 (96hLC50), 0.21 (96hLC0.1) and $0.30 \mathrm{ml} \cdot \mathrm{l}^{-1}$ (96hLC99.9).

Changes in the biochemical blood profile were determined by the biochemical blood plasma analysis using VETTEST 8008 analyser (Medisoft Co.). Biochemical blood profile of rainbow trout was evaluated before anaesthesia with 2-phenoxyethanol at a concentration of $0.30 \mathrm{ml} \cdot \mathrm{l}^{-1}$, immediately after a 10 -min anaesthesia and $24 \mathrm{~h}$ after anaesthesia. A total of 30 fish were examined. While blood plasma glucose (GLU) concentrations immediately after anaesthesia and total proteins (TP), albumins (ALB) and total globulins (GLOB) $24 \mathrm{~h}$ after anaesthesia showed a significant increase, asparate aminotransferase (AST) concentrations immediately after anaesthesia showed a significant decrease. All the changes were significant at the $p<0.05$ level. In other indices [triglycerides (TRIG), cholesterol (CHOL), ammonia $\left(\mathrm{NH}_{3}\right)$, alanine aminotransferase (ALT), alkaline phosphatase (ALP), lactate dehydrogenase (LDH), calcium $\left(\mathrm{Ca}^{2+}\right)$, anorganic phosphate (PHOS)], no differences between the groups studied were found.

The recommended anaesthetic concentration of $0.30 \mathrm{ml} \cdot \mathrm{l}^{-1} 2$-phenoxyethanol can be considered safe for rainbow trout.

LC50, blood plasma, glucose, proteins, enzymes, minerals

One of important pre-requisites for the protection of fish health and for compliance with the Animal Welfare Act 246/1992 Coll. (in the Czech code of laws) is to provide for safe handling of fish and for the prevention of fish injury (damage to the mucosa, deep muscle injuries, gill injuries).

Much attention should be paid to careful and proper handling of brood fish, especially during artificial spawning procedures when fish are handled repeatedly at the time when they are particularly sensitive to mechanical injury. The use of anaesthetics should help prevent mechanical injury to fish, and also facilitate the handling of big fish during veterinary procedures (Čítek et al. 1997; Ross and Ross 1999).

Modern fish anaesthetics must meet a number of general requirements, e.g. they must be highly soluble in water, take effect quickly, be safe for both fish and humans, have broad safety margins, allow an ad libitum intensification of anaesthesia with a possibility of spontaneous recovery, and they must leave no residues in the fish (Brožová and Svobodová 1986; Brown 1988; Ross and Ross 1999).

Address for correspondence:

Ing. Josef Velíšek

University of South Bohemia, Faculty of Agriculture

Department of Anatomy and Physiology of Farm Animals

Studentská 13

37005 České Budějovice

Phone: +420732155886

Fax: + 420387772621

E-mail: velisek.j@centrum.cz

http://www.vfu cz/acta-vet/actavet.htm 
The first use of 2-phenoxyethanol to anaesthetize salmonids was reported in 1963 from Canada (Sehdev et al. 1963; Beel 1964). At present, 2-phenoxyethanol is used in the Czech Republic for short-term immobilization of fish before artificial spawning and whenever fish is handled outside water. The generally recommended concentration is $0.20 \mathrm{ml} \cdot 1^{-1}$ of water bath. For big breeding fish, the recommended concentration is $0.30 \mathrm{ml} \cdot \mathrm{l}^{-1}$ of water bath. At the recommended concentrations, anaesthesia is induced within 5 to $10 \mathrm{~min}$. When transferred to clean water, fish will recover within $10 \mathrm{~min}$ (S v ob od a and Kolářová 1999; Hamáčková et al. 2001).

The aim of the present study was to assess acute toxicity of 2-phenoxyethanol in rainbow trout, and to assess changes in their tissues using biochemical blood profile indices.

\section{Materials and Methods}

2-phenoxyethanol characteristics

The active agent of 2-phenoxyethanol is ethylene glycol monophenyl ether $\left(\mathrm{C}_{8} \mathrm{H}_{10} \mathrm{O}_{2}\right)$. The molar mass of the anaesthetic is $138.17 \mathrm{~g} \cdot \mathrm{l}^{-1}$, its density is $1.107-1.108$, the peroxide content is less than $0.005 \%$, and the boiling point is $245{ }^{\circ} \mathrm{C}$. The anaesthetic is slightly soluble in water $\left(26.7 \mathrm{~g} \cdot \mathrm{l}^{-1}\right)$, but readily soluble in ethanol. The anaesthetic affects fish through skin and gills. Its recommended concentrations are $0.20-0.30 \mathrm{ml} \cdot \mathrm{l}^{-1}$, with the exposure period between 5 and $10 \mathrm{~min}$. It is recommended that the anaesthetic be first mixed well with a small quantity of water before it is poured to the bath. Bath water should have the same characteristics including temperature as the water where the fish were kept. Fish are placed to the bath either individually, or in groups. 2-phenoxyethanol may be administered by a veterinary surgeon or a person authorized by a veterinarian.

The anaesthetic is manufactured by MERCK - Schucherd, 85662 Hohenbrunn, Germany, and supplied in 2.5 and 1 litre canisters, or in other volumes on request.

Acute toxicity test

Rainbow trout (camloops) of $13.25 \mathrm{~g}$ mean body mass $(11.2-15.3 \mathrm{~g})$ and $11.09 \mathrm{~cm}$ mean standard length $(10.5$ - $12 \mathrm{~cm})$, Fulton index $1.01(0.95-1.07)$ were used to ascertain LC50 of 2-phenoxyethanol after $96 \mathrm{~h}$ and $10 \mathrm{~min}$ exposures to the anaesthetic.

In 96-hour LC50 tests, fish were exposed to a range of 2-phenoxyethanol concentrations $(0.05,0.10,0.20,0.30$, 0.40 and $\left.0.50 \mathrm{ml} \cdot \mathrm{1}^{-1}\right)$ in diluting water $\left(\mathrm{pH} 7.81\right.$; acid neutralization capacity $-\mathrm{ANC}_{4.5} 1.15 \mathrm{mmol} \cdot \mathrm{l}^{-1}$; total ammonia $0.04 \mathrm{mg} \cdot 1^{-1} ; \mathrm{NO}^{3-} 11.5 \mathrm{mg} \cdot 1^{-1} ; \mathrm{NO}^{2-} 0.005 \mathrm{mg} \cdot 1^{-1} ; \mathrm{PO}_{4}^{3-} 0.01 \mathrm{mg} \cdot 1^{-1}$; chemical oxygen demand - $\left.\mathrm{COD}_{\mathrm{Mn}} 1.6 \mathrm{mg} \cdot \mathrm{l}^{-1}\right)$, and the controls were placed in diluting water containing no anaesthetic. The fish and its behaviour, water temperature, $\mathrm{pH}$ and oxygen saturation were monitored throughout the tests at individual concentrations and in the control aquarium. Mean lethal concentrations LC50 for 96-hour exposure (96hLC50) and 96hLC0.1 and 96hLC99.9 were computed from those values using the probit analysis (EKO-TOX 5.1 software).

In the $10 \mathrm{~min}$ exposure LC50 tests, fish were exposed to $0.20,0.25,0.30,0.35,0.40,0.45$ and $0.50 \mathrm{ml} \cdot \mathrm{l}^{-1}$ of 2-phenoxyethanol in diluting water for $10 \mathrm{~min}$. Diluting water of the same parameters as in the $96 \mathrm{hLC}$ trials was used. For $10 \mathrm{~min}$, changes in the physiological status, the number of dead fish, and the recovery times of fish placed to clean water were recorded. Mean lethal concentrations LC50 for 10-min exposure (10minLC50) and 10minLC0.1 and 10minLC99.9 were computed from those values using the probit analysis (EKO-TOX 5.1 software).

Changes in the physiological status of anaesthetized fish were assessed in four consecutive stages (Thien point and Niemegeers 1965):

1. acceleration and subsequent deceleration of breathing movements, a partial loss of reactivity to external stimuli

2. loss of balance, breathing movements very slow, fish still reactive to strong stimuli

3. total loss of reactivity, fish are lying at the tank bottom and do not respond to handling

4. complete cessation of opercular movements, fish die if left in the bath for too long.

Biochemical examination of blood plasma

Rainbow trout (camloops) of $27.2 \mathrm{~g}$ mean body mass $(20.4$ - $34 \mathrm{~g}$ ) and $14.86 \mathrm{~cm}$ mean standard length $(13.5-17$ $\mathrm{cm})$, Fulton index $0.98(0.95-1.01)$, were used for the determination of biochemical profile of blood plasma. The biochemical blood plasma profile in rainbow trout was studied before anaesthesia (10 trout), immediately after a 10 min exposure to the anaesthetic (10 trout), and 24 hours after anaesthesia (10 trout). A total of 30 rainbow trout were examined. The fish were anesthetized for $10 \mathrm{~min}$ by 2-phenoxyethanol at a concentration of $0.30 \mathrm{ml} \cdot \mathrm{I}^{-1}$. Blood was collected by a heparinized needle from the heart (after stunning the fish by blow to the head). Aqueous solution of heparin sodium salt was used for blood stabilization (Heparin SPOFA inj. - 1ml aqueous solution contains 5000 i.u. of heparin sodium salt). To stabilize $1 \mathrm{ml}$ of blood, $0.01 \mathrm{ml}$ of aqueous solution of heparin was used (Svobodová et al. 1986).

Blood samples were centrifuged in a cooled centrifuge $\left(4^{\circ} \mathrm{C}, 837 \times \mathrm{g}\right)$. Biochemical indices determined in blood plasma included glucose (GLU), total proteins (TP), albumins (ALB), total globulins (GLOB), ammonia $\left(\mathrm{NH}_{3}\right)$, 
triglycerides (TRIG), cholesterol (CHOL), aspartate aminotransferase (AST), alanin aminotransferase (ALT), alkaline phosphatase (ALP), lactate dehydrogenase (LDH), calcium $\left(\mathrm{Ca}^{2+}\right)$ and inorganic phosphate (PHOS). For the biochemical analysis of blood plasma, VETTEST 8008 (IDEXX Laboratories Inc. U.S.A.) analyser (Medisoft Co.) was used. The apparatus is based upon dry chemical technology and colorimetric reaction. Sample analysis is carried out on selective testing discs (Multi - laier film slides, Kodak) by means of laser reading the bar codes.

For the statistical evaluation, the analysis of variance was used (ANOVA - Tukey Test).

\section{Results}

Acute toxicity of 2-phenoxyethanol

In the 2-phenoxyethanol 96hLC50 tests, water temperature, $\mathrm{pH}$ and oxygen saturation ranges were $15.3-17.5^{\circ} \mathrm{C}, 7.30-8.10$ and $83-102 \%$, respectively. On the basis of tests of acute toxicity to rainbow trout, the 96-hour lethal concentrations of 2-phenoxyethanol were determined as $0.25 \mathrm{ml} \cdot \mathrm{l}^{-1}$ (96hLC50), $0.21 \mathrm{ml} \cdot \mathrm{l}^{-1}$ (96hLC0.1) and $0.30 \mathrm{ml} \cdot \mathrm{l}^{-1}$ (96hLC99.9).

Table 1

Effects of 2-phenoxyethanol anaesthesia on blood plasma indices in rainbow trout. Note: Groups with different alphabetic superscripts differ significantly at $p<0.05$ (ANOVA).

\begin{tabular}{|c|c|c|c|}
\hline Indices & $\begin{array}{c}\text { Control } \\
\mathrm{x} \pm \operatorname{SD}(\mathrm{n}=10)\end{array}$ & $\begin{array}{c}\text { Immediately after } \\
\text { anaesthesia } \\
\mathrm{x} \pm \mathrm{SD}(\mathrm{n}=10)\end{array}$ & $\begin{array}{c}24 \mathrm{~h} \text { after anaesthesia } \\
\mathrm{x} \pm \mathrm{SD}(\mathrm{n}=10)\end{array}$ \\
\hline $\mathrm{GLU}\left(\mathrm{mmol} \cdot \mathrm{l}^{-1}\right)$ & $6.85 \pm 0.86^{\mathrm{a}}$ & $8.36 \pm 1.25^{b}$ & $6.17 \pm 0.74^{\mathrm{a}}$ \\
\hline $\mathrm{TP}\left(\mathrm{g} \cdot \mathrm{l}^{-1}\right)$ & $29.25 \pm 0.64^{a}$ & $31.17 \pm 0.81^{\mathrm{a}}$ & $43.50 \pm 1.11^{b}$ \\
\hline $\operatorname{ALB}\left(\mathrm{g} \cdot \mathrm{l}^{-1}\right)$ & $4.0 \pm 1.0^{\mathrm{a}}$ & $4.0 \pm 1.0^{\mathrm{a}}$ & $11.0 \pm 1.0^{b}$ \\
\hline GLOB $\left(\mathrm{g} \cdot \mathrm{l}^{-1}\right)$ & $25.25 \pm 1.00^{\mathrm{a}}$ & $27.17 \pm 1.00^{\mathrm{a}}$ & $32.5 \pm 1.0^{b}$ \\
\hline $\mathrm{NH}_{3}\left(\mathrm{mmol} \cdot \mathrm{l}^{-1}\right)$ & $757.25 \pm 9.16^{\mathrm{a}}$ & $765.33 \pm 11.30^{\mathrm{a}}$ & $736.83 \pm 10.40^{\mathrm{a}}$ \\
\hline TRIG $\left(\mathrm{mmol} \cdot \mathrm{l}^{-1}\right)$ & $0.82 \pm 0.64^{\mathrm{a}}$ & $0.82 \pm 0.48^{\mathrm{a}}$ & $0.70 \pm 0.61^{\mathrm{a}}$ \\
\hline $\mathrm{CHOL}\left(\mathrm{mmol} \cdot \mathrm{l}^{-1}\right)$ & $1.97 \pm 0.22^{\mathrm{a}}$ & $1.87 \pm 0.22^{\mathrm{a}}$ & $1.96 \pm 0.24^{\mathrm{a}}$ \\
\hline $\operatorname{AST}\left(\mathrm{mkat}^{\left.-1^{-1}\right)}\right.$ & $5.16 \pm 0.04^{a}$ & $4.10 \pm 0.04^{b}$ & $5.15 \pm 0.04^{\mathrm{a}}$ \\
\hline ALT (mkat $\left.\cdot l^{-1}\right)$ & $0.37 \pm 0.03^{\mathrm{a}}$ & $0.34 \pm 0.04^{\mathrm{a}}$ & $0.39 \pm 0.04^{a}$ \\
\hline $\operatorname{ALP}\left(\mathrm{mkat}^{-1^{-1}}\right)$ & $0.56 \pm 0.02^{\mathrm{a}}$ & $0.54 \pm 0.02^{\mathrm{a}}$ & $0.49 \pm 0.03^{\mathrm{a}}$ \\
\hline LDH (mkat $\left.\cdot \mathrm{l}^{-1}\right)$ & $18.20 \pm 0.19^{a}$ & $18.00 \pm 0.16^{\mathrm{a}}$ & $18.10 \pm 0.17^{\mathrm{a}}$ \\
\hline PHOS $\left(\mathrm{mmol} \cdot \mathrm{l}^{-1}\right)$ & $3.70 \pm 0.04^{\mathrm{a}}$ & $3.70 \pm 0.07^{\mathrm{a}}$ & $3.40 \pm 0.12^{\mathrm{a}}$ \\
\hline $\mathrm{Ca}^{2+}\left(\mathrm{mmol} \cdot \mathrm{l}^{-1}\right)$ & $2.93 \pm 0.07^{\mathrm{a}}$ & $2.86 \pm 0.27^{\mathrm{a}}$ & $2.85 \pm 0.24^{\mathrm{a}}$ \\
\hline
\end{tabular}

A post mortem examination of the fish after acute toxicity tests showed increased presence of aqueous mucous and a dark discolouration of the dorsum. The gills were mat dark in colour and bled readily when injured. The body cavity contained excess moisture, and an increased injection of visceral vessels was also observed. These findings indicated that anaesthetized fish were more sensitive to mechanical injury.

During the 10-min LC50 tests, water temperature was $15^{\circ} \mathrm{C}$, pH was 7.75 and the water oxygen saturation was $98 \%$. The effect of 2-phenoxyethanol concentrations on the onset of individual phases of anaesthesia and recovery is shown in Fig. 1. On the basis of tests of acute toxicity to rainbow trout, lethal concentrations of 2-phenoxyethanol at 10-min exposure were computed (10minLC50: $0.46 \mathrm{ml} \cdot \mathrm{l}^{-1}, 10 \mathrm{minLC} 0.1$ : $0.34 \mathrm{ml} \cdot \mathrm{l}^{-1}$ and 10minLC99.9: $0.92 \mathrm{ml} \cdot \mathrm{l}^{-1}$ ).

Biochemical blood plasma profile after 2-phenoxyethanol exposure

Effects of 2-phenoxyethanol on the blood plasma biochemical profile of rainbow trout are given in Tab. 1. At a 10 minute exposure to 2-phenoxyethanol at the concentration of 0.30 $\mathrm{ml} \cdot \mathrm{l}^{-1}$, the total proteins (TP) values increased from $29.25 \pm 0.64 \mathrm{~g} \cdot \mathrm{l}^{-1}$ to $43.5 \pm 1.11 \mathrm{~g} \cdot \mathrm{l}^{-1}$ in 24 hours after anaesthesia. Albumin (ALB) values increased markedly from $4 \pm 1.0 \mathrm{~g} \cdot 1^{-1}$ to $11 \pm 1.0 \mathrm{~g} \cdot \mathrm{l}^{-1}$ in 24 hours after anaesthesia. Total globulins (GLOB) values 24 hours after anaesthesia were up to $32.5 \pm 1.0 \mathrm{~g} \cdot \mathrm{l}^{-1}$ from $25.25 \pm 1.0 \mathrm{~g} \cdot \mathrm{l}^{-1}$. Glucose (GLU) values 
increased from $6.85 \pm 0.86 \mathrm{mmol} \cdot \mathrm{l}^{-1}$ to $8.36 \pm 1.21 \mathrm{mmol} \cdot \mathrm{l}^{-1}$ immediately after anaesthesia. Alanine aminotransferase (AST) values decreased markedly from $5.16 \pm 0.04 \mu \mathrm{kat} \cdot \mathrm{l}^{-1}$ to $4.10 \pm 0.04 \mu \mathrm{kat} \cdot \mathrm{l}^{-1}$ immediately after anaesthesia. All the changes were significant at the $p<0.05$ level. In other indices (TRIG, $\mathrm{NH}_{3}, \mathrm{ALT}, \mathrm{ALP}, \mathrm{LDH}, \mathrm{CHOL}, \mathrm{Ca}^{2+}$ and PHOS), no statistically significant differences between experimental groups were observed.

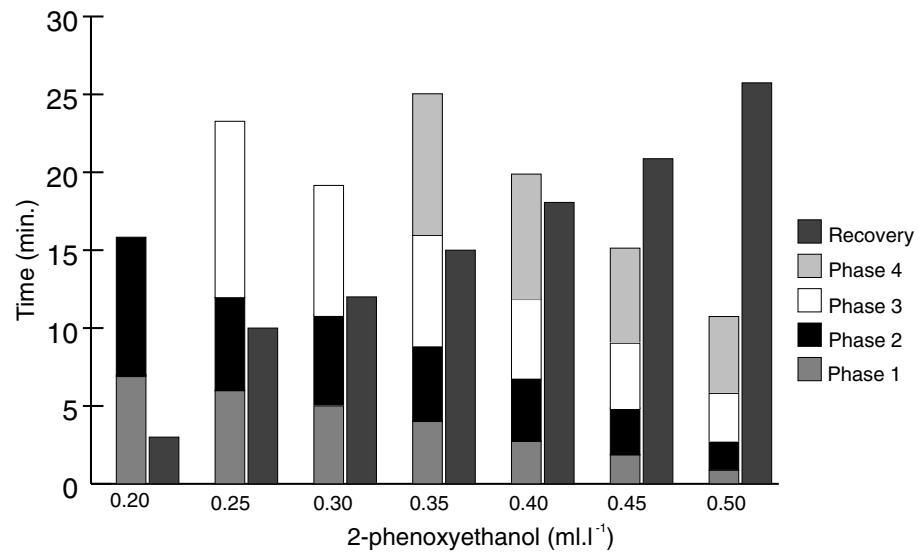

Fig 1. The effect of concentration of 2-phenoxyethanol on the onset of individual phases of anaesthesia and recovery in rainbow trout (Oncorhynchus mykiss).

\section{Discussion}

The 96LC50 value of $0.25 \mathrm{ml} \cdot \mathrm{l}^{-1}$ found in the study suggests that 2-phenoxyethanol is relatively harmless for fish. The fish, however, were exposed to the anaesthetic for $10 \mathrm{~min}$ only. The 10minLC50 value in rainbow trout is about twice as high as the 96hLC50 value. In spite of that, the therapeutic index, i.e. the ratio between the therapeutic and the lethal concentrations, is very low $(0.46: 0.30)$. The $10 \mathrm{minLC} 0.1$ value found in the present study $\left(0.34 \mathrm{ml} \cdot \mathrm{l}^{-1}\right)$ is also below the concentration threshold recommended for anaesthesia $\left(0.30 \mathrm{ml} \cdot \mathrm{l}^{-1}\right)$. For that reason, it is essential that recommended procedures for sedation be strictly observed to prevent injury to fish.

Another aspect in favour of using 2-phenoxyethanol for rainbow trout at the concentration of $0.30 \mathrm{ml} \cdot \mathrm{l}^{-1}$ is that the $10 \mathrm{minLC} 50$ values were recorded for water temperature of $15^{\circ} \mathrm{C}$. A majority of both breeding and veterinary interventions in rainbow trout takes place at much lower temperatures $\left(5-7{ }^{\circ} \mathrm{C}\right)$. Under such conditions, $10 \mathrm{minLC50}$ values will probably be higher. Weyl et al. (1996) and Hamáčková et al. (2001) stated that the most important factor influencing 2-phenoxyethanol efficacy in fish is temperature, i.e. the higher the temperature, the higher the efficiency of the anaesthetic for fish.

Sensitivity to anaesthetics may also be influenced by fish health and physical condition. Sensitivity to anaesthetics is also influenced by oxygen concentrations in the sense that oxygen deficit enhances the anaesthetic efficiency (Svobodová et al. 1987).

Because juvenile fish are more sensitive to 2-phenoxyethanol than adult fish, lower concentrations of the anaesthetic should be used for the former, as they provide much wider safety margins for anaesthesia (Barton and Helfrich 1981).

The same authors (Barton and Helfrich 1981) recommend that $0.30-0.40 \mathrm{ml} \cdot \mathrm{l}^{-1}$ and $0.25 \mathrm{ml} \cdot \mathrm{l}^{-1}$ of 2-phenoxyethanol for 10 minutes be used to anaesthetize adult and juvenile rainbow trout, respectively. Nog a (1996), recommends the same concentrations but shorter exposure times $(2-4 \mathrm{~min})$. 
It has been demonstrated that onset times of individual stages of 2-phenoxyethanol anaesthesia as well as recovery times (Fig. 1) were concentration-dependent. The influence of anaesthetic concentrations on anaesthesia induction times has been corroborated by Myszkowski et al. (2002) and Weyl et al. (1996).

The biochemical profile of blood can provide important information about the internal environment of the organism (Ma sopust 2000).

Increased blood plasma glucose concentrations immediately after 2-phenoxyethanol anaesthesia indicate that the procedure caused some stress in the trout, but the values returned to normal in 24 hours. The AST decrease in blood plasma indicates that the anaesthetic does not damage parenchymatous tissues in rainbow trout.

Torta et al. (2002) reported that 2-phenoxyethanol anaesthesia did not reduce cortisol levels in rainbow trout, did not block stress and had no negative effect on blood indices, i.e. the haematocrit value (PCV), haemoglobin content $(\mathrm{Hb})$, erytrocyte count (RBC), mean corpuscular volume (MVC), mean corpuscular haemoglobin $(\mathrm{MCH})$ and mean corpuscular haemoglobin concentration (MCHC).

Ortuno et al. (2002) reported an increase in glucose and cortisol values in Sparus aurata anaesthetized with 2-phenoxyethanol.

Anaesthesia with 2-phenoxyethanol at the concentration of $400 \mathrm{ppm}$ and 2 min exposure time had no effect on tryptophan, 5-hydroxytryptamine, dopamine or norepinephrine levels in the brain of rainbow trout (Sloley et al. 1986).

When 2-phenoxyethanol is used, labour safety regulations should be strictly observed because the anaesthetic is toxic and harmful to humans. In poorly ventilated rooms, it may cause fatigue and drowsiness of the staff (S voboda and Kolářová 1999).

\section{Anestezie pstruha duhového (Oncorhynchus mykiss) 2-phenoxyethanolem: akutní toxicita a vliv na biochemický profil krve}

Cílem práce bylo posoudit akutní toxicitu a pomocí hodnot biochemického profilu krve zhodnotit změny ve tkáních pstruha duhového po působení anestetika 2-phenoxyethanolu. Ke stanovení akutní toxicity byla použita metoda OECD 203 „Test akutní toxicity na rybách“. Zjištěné hodnoty akutní toxicity 2-phenoxyethanolu pro pstruha duhového $\left(\mathrm{Pd}_{1 / 2}\right)$ byly následující 10minLC50 0.46; 10minLC0.1 0.34; 10minLC99.9 $0.92 \mathrm{ml}^{-1} \mathrm{l}^{-1}$; 96hLC50 $0.25 ; 96 \mathrm{hLC} 0.10 .21 ; 96 \mathrm{hLC} 99.90 .30 \mathrm{ml} \cdot \mathrm{l}^{-1}$.

Stanovení změn biochemického profilu krve bylo provedeno biochemickou analýzou krevní plazmy na analyzátoru VETTEST 8008 firmy Medisoft. Biochemický profil krve byl hodnocen u pstruhů duhových před, ihned po 10minutové anestézii a 24 hodin po anestézii v koncentraci $0.30 \mathrm{ml} \cdot \mathrm{l}^{-1}$ 2-phenoxyethanolu. Celkem bylo vyšetřeno $30 \mathrm{kusů} \mathrm{ryb}$ $\mathrm{Pd}_{1 / 2}$. Významné zvýšení hodnot ukazatelů v krevní plazmě bylo zjištěno u glukózy (GLU) ihned po anestézii a u celkových bílkovin (TP), albuminů (ALB) a globulinů (GLOB) 24 hodin po anestézii a výrazné snížení koncentrace aspartát aminotransferázy (AST) ihned po anestézii. Všechny rozdíly byly na hladině významnosti $p<0.05$. U ostatních sledovaných ukazatelů [(triglyceridy (TRIG), cholesterol (CHOL), amoniak $\left(\mathrm{NH}_{3}\right)$, alanin aminotransferáza (ALT), alkalická fosfatáza (ALP), laktát dehydrogenáza (LDH), kalcium $\left(\mathrm{Ca}^{2+}\right)$, anorganický fosfát (PHOS)] nebyly zjištěny rozdíly mezi posuzovanými skupinami.

Koncentrace $0.30 \mathrm{ml} \cdot \mathrm{l}^{-1}$ 2-phenoxyethanolu doporučovaná $\mathrm{k}$ anestézii se pro pstruha duhového jeví jako bezpečná.

\section{Acknowledgement}

The present study was conducted as part of the NAZV GF3029 Project of Harmonization with the EU in applying pharmacovigilance principles in aquaculture in the Czech Republic and the project MSM 126100003. 


\section{References}

BARTON, BA, HELFRICH, H 1981: Time-dose responses of juvenile rainbow trout to 2-phenoxyethanol. Prog Fish Cult 43: 223-231

BEEL, GR 1964: A guide to properties, characteristics, and uses of some general anesthesia for fish. Bull Fish Res Bd Can 148: 203-206

BROŽOVÁ V, SVOBODOVÁ, Z 1986: Anaesthetics for fish. Bull VÚRH Vodňany 20: 36-40 (In Czech)

BROWN, LA 1988: Tropical fish medicine. Anesthesia in fish. Vet Clin Nort Am Small Anim Prac 18: $317-330$

ČÍTEK, J, SVOBODOVÁ, Z, TESAŘÍK, J 1997: Diseases of freshwater and aquarium fish. Informatorium Praha 218 p. (In Czech)

HAMÁC̆KOVÁ, J, SEDOVA, JM, PJANOVA, SV, LEPIČOVÁ, A 2001: The effect 2-phenoxyethanol, clove oil and Propiscin anaesthetics on perch (Perca fluviatilis) in relation to water temperature. Czech J Anim Sci 46: 469-473

NOGA, EJ 1996: Fish disease: Diagnosis and treatment. Mosby St. Louis 292 p.

MYSZKOWSKI, L, KAMINSKI, R, WOLNICKI, J 2002: Response of juvenile tench Tinca tinca (L.) to 2-phenoxyethanol. J Fish Biol 23: 400-430

MASOPUST, J 2000: Clinical biochemistry. Karolinum Praha 429 p. (In Czech)

OTRUNO, J, ESTEBAN, MA, MESEGUER, J 2002: Lack of effect of combining different stressors on innate immune responses of sea bream (Sparus aurata L.). Vet Immunol Immunopathol 84: 17-27

ROSS, LG, ROSS B 1999: Anaesthetic and sedative techniques for aquatic animals. Second Edition, Oxford, Blackwell Science Ltd. 159 p.

SEHDEV, HS, McBRIDE, JR, FAGERLUND, UHM 1963: 2-phenoxyethanol as general anaesthetic for sockeye salmon. J Fish Res Bd Can 20: 1435-1440

SLOLEY, BD, HICKIE, BE, DIXON, DG 1986: The effect of sodium pentachlorophenate, diet and sampling procedure on amine and tryptophan concentrations in the brain of rainbow trout, Salmo gardneri Richardson. J Fish Biol 28: 267-277

SVOBODA, M, KOLÁŘOVÁ, J 1999: A survey of anaesthetics used in the fish farming. Health protection of fish - proceeding of papers. VÚRH Vodňany pp 49-72 (In Czech)

SVOBODOVÂ, Z, PRAVDA, D, PALÁČKOVÁ, J 1986: Unified methods of haematological examination of fish. Research Institute of Fish Culture and Hydrobiology, Vodňany, Methods No. 20, 31 p.

SVOBODOVÁ, Z GELNEROVÁ, J, JUSTÝN, J, KRUPAUER, V, MÁCHOVÁ, J, SIMANOV, L, VALENTOVÁ, O, VYKUSOVÁ, B, WOHLGEMUTH, E 1987: Toxicology of aquatic animals. SZN Praha 231 p. (In Czech)

THIENPOINT, D, NIEMEGEERS, CJE 1965: R 7464- a new potent anaesthetic in fish. International Zoo Yearbook 5: 202-205

TORT, L, PUIGCERVER, M, CRESPO, S, PADROS, F, 2002: Cortisol and haematological response in sea bream and trout subjected to the anaesthetics clove oil and 2-phenoxyethanol. Aquaculture Res 33: 907-910

WEYL, O, KAISER, H, HECHT, T 1996: On efficacy and mode of 2-phenoxyethanol as an anesthetic for gold fish, Carassius auratus (L.), at different temperatures and concentrations. Aquaculture Res 27: 757-764 